\title{
Prone mechanical ventilation in acute brain injury
}

Varun Suresh ${ }^{1 *}$ and Saurabh Sharma ${ }^{2}$

\section{Dear Editor,}

We read with great interest the research work by Bernon and colleagues [1] that retrospectively analyses the influence of prone positioning (PP) on intracranial pressure (ICP) in acute brain injury. The study elucidates acute ICP changes within an interval of $1-h$, following PP, as a safe limit to decide on pursuing this manoeuvre further in acute brain injury; nevertheless, we have a few concerns regarding this retrospective analysis.

We could not infer the exact technique of measurement of ICP in this retrospective study. Multiple invasive and non-invasive methods are available to measure ICP, each with its own strengths and limitations [2]. It is understood from the study results that seven patients in each group (raised ICP versus normal ICP) had external ventricular drains (EVD). Among patients with EVD, ICP is frequently measured using the same ventricular access [3]. Hence, we infer that to ensure uniformity of ICP data studied the authors must have used intra-parenchymal catheter-based technique of ICP measurement. We would also like to know whether such technique used was similar across all the study patients.

We also categorically comment on the wide heterogeneity among this small study population. The ICP dynamics and cerebral autoregulation vary widely across patients with traumatic brain injury, aneurysmal subarachnoid haemorrhage and hemorrhagic stroke. Hence, we presume this heterogeneity contributed to the insignificant results of PP on ICP among patients whom underwent major ICP lowering interventions like

*Correspondence: varunsureshpgi@gmail.com

${ }^{1}$ Department of Anaesthesiology, Government Medical College, Thiruvananthapuram, Kerala 695011, India

Full list of author information is available at the end of the article craniectomy $(p=0.595)$, barbiturate coma $(p=0.694)$ and osmotherapy $(p=0.440)$.

We would also argue against using a uniform positive end expiratory pressure (PEEP $=10 \mathrm{mmHg}$ ) among patients with and without raised ICP. A high PEEP can contribute to disputed ICP readings in patients with autoregulatory failure as seen in some cases of intracranial hypertension $[4,5]$.

That the narration by Bernon and colleagues favour non-invasive methods of cerebral compliance assessment like the transcranial Doppler in acute brain injury, prior to protective lung ventilation interventions, is highly appreciated. Yet a clarification on our concerns shall add more to the understanding of the readers.

\section{Acknowledgements}

None.

\section{Authors' contributions}

VS and SS equally contributed to conceptualisation of idea, preparing manuscript draft with literature review, final review and approval of the manuscript. Both authors read and approved the final manuscript.

\section{Funding}

The authors declare no funding sources for writing this manuscript.

Availability of data materials

Not applicable.

\section{Declarations}

Ethical approval and consent to participate Not applicable.

\section{Consent for publication}

Not applicable.

\section{Competing interests}

The authors declare no competing interests.

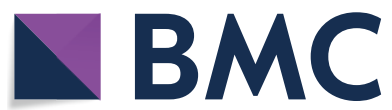

(c) The Author(s) 2021. Open Access This article is licensed under a Creative Commons Attribution 4.0 International License, which permits use, sharing, adaptation, distribution and reproduction in any medium or format, as long as you give appropriate credit to the original author(s) and the source, provide a link to the Creative Commons licence, and indicate if changes were made. The images or other third party material in this article are included in the article's Creative Commons licence, unless indicated otherwise in a credit line to the material. If material is not included in the article's Creative Commons licence and your intended use is not permitted by statutory regulation or exceeds the permitted use, you will need to obtain permission directly from the copyright holder. To view a copy of this licence, visit http://creativecommons.org/licenses/by/4.0/. The Creative Commons Public Domain Dedication waiver (http://creativeco mmons.org/publicdomain/zero/1.0/) applies to the data made available in this article, unless otherwise stated in a credit line to the data. 


\section{Author details}

${ }^{1}$ Department of Anaesthesiology, Government Medical College, Thiruvananthapuram, Kerala 695011, India. ${ }^{2}$ Department of Neuro-Anesthesia and Neuro-Critical Care, Kalinga Institute of Medical Sciences, Bhubaneswar, Odisha 751024, India.

Received: 11 February 2021 Accepted: 4 March 2021

Published online: 10 March 2021

\section{References}

1. Bernon P, Mrozek S, Dupont G, Dailler F, Lukaszewicz AC, Balança B. Can prone positioning be a safe procedure in patients with acute brain injury and moderate-to-severe acute respiratory distress syndrome? Crit Care. 2021;25(1):30

2. Harary M, Dolmans RGF, Gormley WB. Intracranial pressure monitoringreview and avenues for development. Sensors (Basel). 2018;18(2):465.
3. Muralidharan R. External ventricular drains: management and complications. Surg Neurol Int. 2015;6(Suppl 6):S271-4.

4. Li HP, Lin YN, Cheng ZH, Qu W, Zhang L, Li QY. Intracranial-to-central venous pressure gap predicts the responsiveness of intracranial pressure to PEEP in patients with traumatic brain injury: a prospective cohort study. BMC Neurol. 2020;20(1):234.

5. Chen H, Chen K, Xu JQ, Zhang YR, Yu RG, Zhou JX. Intracranial pressure responsiveness to positive end-expiratory pressure is influenced by chest wall elastance: a physiological study in patients with aneurysmal subarachnoid hemorrhage. BMC Neurol. 2018;18(1):124.

\section{Publisher's Note}

Springer Nature remains neutral with regard to jurisdictional claims in published maps and institutional affiliations.
Ready to submit your research? Choose BMC and benefit from:

- fast, convenient online submission

- thorough peer review by experienced researchers in your field

- rapid publication on acceptance

- support for research data, including large and complex data types

- gold Open Access which fosters wider collaboration and increased citations

- maximum visibility for your research: over 100M website views per year

At BMC, research is always in progress.

Learn more biomedcentral.com/submissions 